Theological Research • volume 8 (2020) • P. 7-2I

doi: https://doi.org/IO.15633/thr.4I25

OSKARI JUURIKKALA

https://orcid.org/0000-0003-2273-3574

Åbo Akademi University, Finland

Pontifical University of the Holy Cross, Italy

\title{
The Ontology of Theosis: Insights from Maximus the Confessor
}

\section{Abstract}

This article describes the ontological problem of theosis or deification in terms of two dimensions: the relationship between the finite and the infinite, and the relationship between human nature and sin. Both problems are clarified through the thinking of Saint Maximus the Confessor and his distinction between logos and tropos, that is, the constitutive nature of a thing and its existential mode of being. Theosis is presented not as a transformation of the human nature, but a transformation of our mode of being by its healing and elevation by divine grace. Maximus' theological anthropology explains how the effects of sin should not be situated at the level of human nature but its mode of being. His conceptual distinctions may help to clarify the thought of Luther, at least as it is presented in the Finnish interpretation of Luther.

KeYWORDS

deification, Finnish Luther, Maximus the Confessor, theosis 


\section{INTRODUCTION}

This paper looks at the ontological problem of the doctrine of theosis (or the divinisation of the human being) from the viewpoint of Saint Maximus the Confessor (c. 580-662) and tries to draw some insights that may be of use in dialogue with Lutheran theology. ${ }^{\mathrm{I}}$ In synthesis, the ontological problem of theosis consists of two issues: on the one hand, the relationship between the finite and the infinite (or the created and the uncreated); on the other hand, the relationship between human nature and sin. The latter issue is particularly pertinent to the question of whether a meaningful doctrine of theosis may be discerned in or at least derived from the writings of Martin Luther, as has been famously claimed by Tuomo Mannermaa and his disciples. ${ }^{2}$

I have chosen to look at the question from the viewpoint of Maximus the Confessor, a leading figure of the later patristic era, first of all because he is often seen as a bridge-builder between different traditions: East and West, Platonic and Aristotelian, and so on. ${ }^{3}$ His understanding and interpretation of the patristic doctrine of theosis is particularly interesting in that it is conceptually precise, and it embraces the full force of that doctrine while also somehow conserving the value of the

I An earlier version of this article was presented at the conference Re-thinking Ontology with Luther, organized at the Pontifical University of the Holy Cross, Rome, 3-4 May 20I8. I am very grateful to the conference participants for feedback and discussion.

2 See the seminal work Tuomo Mannermaa, Christ Present In Faith: Luther's View Of Justification, Minneapolis 2005. It was originally published in Finnish with the Latin title In ipsa fide Christus adest (1979), and was based on a discourse that was part of an ecumenical dialogue between the Evangelical-Lutheran Church of Finland and the Russian Orthodox Church. The principal claim of the Mannermaa school is that Luther's view of justification actually amounts to, or least comes very close, the Eastern patristic doctrine of deification (theosis). This interpretation entered the English-speaking Lutheran world more recently, causing quite a stir; for a collection of valuable papers, see: Union with Christ: The New Finnish Interpretation of Luther, eds. C.E. Braaten, R.W. Jenson, Grand Rapids 1998. Understandably, not everyone has embraced the Finnish interpretation.

3 There is burgeoning Maximus scholarship at present; for a series of recent studies with ample references to previous research, see The Oxford Handbook of Maximus the Confessor, eds. P. Allen, B. Neil, Oxford 2015. 
created sphere. Maximus was able to address both of the two principal ontological issues, mentioned above, given his extensive metaphysics of participation and his Christologically reformulated cosmology that was inspired by his meditation on the mystery of Christ's humanity.

There are already several excellent studies on Maximus' doctrine of theosis, so I will begin by providing a schematic outline of some of its key characteristics and solutions. ${ }^{4}$ First, I will highlight the distinction between logos and tropos, which is the conceptual key to Maximus' solutions. Next, I explain the two steps of deification, namely the Incarnation and the participation of the human creature in this gift through union with Christ. We will then turn to the problem of sin and how the logos/tropos distinction can help to clarify the transformation produced by grace in the deification of the human creature. The article ends with a brief discussion of the Finnish interpretation of Luther and what Maximus might add to the question.

\section{Conceptual Key: The Logos/Tropos Distinction}

Maximus' understanding of theosis is part of a broader vision of the ground and goal of creation, which is the union between God and the world. The way Maximus understands this purpose is rooted in a radically Christocentric metaphysics, which entails a reinterpretation of Neoplatonic and Aristotelian principles. Deification or theosis is understood as perfect participation in the Trinity, with total identity and total difference. ${ }^{5}$ One of the syntheses of Maximus' ontology

4 There are a number of extensive studies, with some differences of emphases and interpretation. For the first section I have especially benefitted from the simple but precise exposition of J.-C. Larchet, The Mode of Deification, in: The Oxford Handbook of Maximus the Confessor, op. cit., pp. 34I-59. For more detailed studies, see J.M. Garrigues, Maxime le Confesseur: La Charité, avenir divin de l'homme, Paris i976; J.-C. Larchet, La divinisation de l'homme selon saint Maxime le Confesseur, Paris 1996; E. Perl, Methexis: Creation, Incarnation, Deification in Saint Maximus Confessor, $\mathrm{PhD}$ dissertation, Yale University 199r; L. Thunberg, Man and the Cosmos: The Vision of St. Maximus the Confessor, Crestwood 1985; L. Thunberg, Microcosm and Mediator: The Theological Anthropology of Maximus the Confessor, 2nd ed., Chicago 1995 .

5 This is the central thesis of E. Perl, Methexis: Creation, Incarnation, Deification in Saint Maximus Confessor, op. cit. 
may be found in the celebrated phrase, according to which "the Logos of God [...] wills always and in all things to accomplish the mystery of his embodiment." 6

The way Maximus presents this conceptually builds on a general distinction used widely in his writings, namely the distinction between logos and tropos. ${ }^{7}$ These words cannot be readily translated into modern languages, but what Maximus means by them is relatively straightforward. Logos refers to the essential definition, that which constitutes the nature of a thing, and always carries the connotation of invariance. Tropos signifies a mode of being or a way of being, which is more subject to change.

Both terms have many specific meanings in different contexts, but their key uses in Maximus' writings can be synthesized as follows. Firstly, they are used to account for how the reality of our natural (created, finite) order can attain to a new, supernatural (uncreated, infinite) order without ceasing to be of the created order. Secondly, they are used to account for how Christ could have had a fully human nature (including human will), that is, the same nature and the same natural will with us, without having a disordered will (inclined to sin, opposed to God's will).

We will come to both of these two uses shortly in more detail, but the crucial point is this: theosis is seen as taking place not in the principle or logos of the human nature (bologos tês physeôs), but in the change of the mode of being (ho tropos tês hyparxeôs). For Maximus, this is not a special case, but reflects a general principle of innovation, as he explains in a passage of the Ambigua [=Amb.] ("The Book of Difficulties," Maximus' principal speculative work):

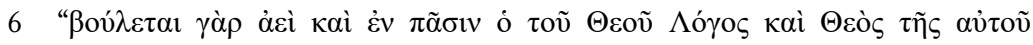

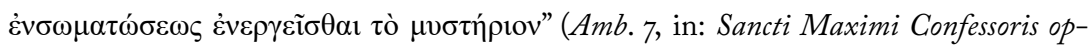
era omnia, ed. J.-P. Migne, Parisiis I865 (Patrologiae Cursus Completus. Series Graeca [= PG] 9I), col. $\mathrm{Io}_{4} \mathrm{D}$ ).

7 For more details, see for example P. Sherwood, The Earlier "Ambigua" of Saint Maximus the Confessor and His Refutation of Origenism, Rome 1955, pp. I64-I66; L. Thunberg, Microcosm and Mediator, op. cit., pp. 415-418; J.-C. Larchet, La divinisation de l'homme selon saint Maxime le Confesseur, op. cit., pp. I4I-I5I, 265-273, 347-355, $605-608$. 
Every innovation, generally speaking, takes place in relation to the mode of whatever is being innovated, not in relation to its principle [logos] of nature, because when a principle is innovated it effectively results in the destruction of nature, since the nature in question no longer possesses inviolate the principle according to which it exists. When, however, the mode [tropos] is innovated-so that the principle of nature is preserved inviolate-it manifests a wondrous power, for it displays nature being acted on and acting outside the limits of its own laws. ${ }^{8}$

In other words, the innovation that takes place in creatures does not change their permanent principle of nature but makes them go beyond the previous manifestations and possibilities of their mode of being, therefore also potentially going beyond their own laws. Maximus argues that this is a general principle: "whenever God [...] wishes to manifest something new in his creation," he does not destroy the nature constituted in creation but enables the creature to act and be acted upon in new ways. ${ }^{9}$

\section{The Incarnation: The Principle of the Deification of Human Nature}

The central and paradigmatic case of such acting and being acted upon takes place in the humanity of Christ. Indeed, the fundamental basis of the deification or divinisation of the human being is the Incarnation of the divine Logos. ${ }^{\mathrm{o}}$ The Incarnation entails the perichoresis or mutual compenetration of the Christ's human and divine natures in the hypostatic union. The humanity of Christ is truly and fully human, but in several passages, Maximus insists that Christ is not a mere human being.

8 Amb. 42 (PG 9I, $\mathrm{I}_{34 \mathrm{ID}}$ ). The English translations of the Ambigua according to Maximus the Confessor, On Difficulties in the Church Fathers: The Ambigua, ed. and trans. N. Constas, 2 vols., Cambridge, MA $20 \mathrm{I}_{4}$ (Dumbarton Oaks Medieval Library 28-29).

9 See $A m b \cdot 4^{2}$ (I344A).

Io See generally J.-C. Larchet, La divinisation de l'homme selon saint Maxime le Confesseur, op. cit., pp. 221-362. 
He explains this using the logos/tropos dyad, commenting on the following phrase of Pseudo-Dionysius: "He became a human being in a manner beyond being, and in a manner beyond the human he works the things of a human being." Maximus explains that the innovation operating here pertains not to the principle of human nature but the mode (tropos) of its being, which being thus lifted up, operates in a manner beyond the human. This is possible, because in Christ, "the human activity is conjoined with the divine power, since the human nature, united without confusion to the divine nature, is completely penetrated by it."Yet it is not that Christ has a different humanity, but his humanity has a different, transcendent tropos or mode of being, because the Word has "united his transcendent mode of being with the principle of his human nature, so that the ongoing existence of that nature might be confirmed by the newness of the mode of being." "II

The first step of theosis, then, is the Incarnation, which through the hypostatic union of Christ's two natures leads to the perichoresis or compenetration of human and divine natures so that the former is raised by the latter to a new mode of existence without however changing its essence or logos. In the words of Sherwood, "the [human] nature and will are wholly divinized, not as to their nature, which remain ever human, but according to the mode of their existence [which is divine]. This is the mystery of Christ."

Maximus insists that the logos of human nature remains unchanged; otherwise, it would cease to be what it is. Moreover, it could not function as a point of union between us and God. However, what changes is its mode (tropos), or state (hexis), or quality (poiotês). Larchet further points out that it would be erroneous to locate the change simply to the level of the person, saying that the person is deified. This way of speaking does not correspond to Maximus' intention, and it is clear that it could not be meaningfully applied to the paradigmatic case, namely the divinisation of human nature in Christ, because the person of Christ is already divine. "If deification has a meaning, it can

II Ambigua ad Thomam, 5, in: Maximus Confessor-Ambigua ad Thomam una cum Epistula secunda ad eundem, ed. B. Janssens, Turnhout 2002, p. 27 (Corpus Christianorum Series Greaeca 48).

I2 P. Sherwood, The Earlier "Ambigua" of Saint Maximus the Confessor, op. cit., pp. $57-58$. 
only be with respect to his human nature and relate to a mode of that nature's existence." ${ }^{3}$

\section{The Deification of the Human Creature}

The second step is the deification of the human creature through union with Christ, leading to a transformation in which the human being is taken to a mode of being beyond the limits of human nature. Maximus uses terms like ecstasy to express the process: in theosis, human beings go out of themselves and are elevated beyond themselves. In Larchet's words, they are "enveloped and penetrated" by God and his divine activity, "which has come to them and operates in them by their free consent." ${ }^{14}$

Maximus describes this using classical images that evoke a union without confusion and a transformation that allows what is transformed to keep its essential identity: air illuminated by light, iron set ablaze by fire, and a sword, plunged into the fire, the edge of which becomes red hot. Although the fullness of this process takes place in heaven, according to Maximus it already happens imperfectly in saints on earth; these are the first fruits of future deification.

Importantly, not only the humanity of Christ but the deified humanity of all the saints transcends the limits of their own nature. The fully divinised human nature is no longer governed by its previous laws, and the penetrating and enveloping grace will ultimately defeat even the marks of human nature, not because the nature itself is abolished, but because its mode of being is raised. Thus, Maximus describes the state of saints as follows: "Having been wholly united with the whole Word, within the limits of what their own inherent natural potency allows, $[\ldots]$ they possess the fullness of his divine characteristics, yet none of the original attributes that naturally define human beings have been lost, for all things have simply yielded to what is better, like airwhich in itself is not luminous-completely mixed with light." ${ }^{15}$

I3 J.-C. Larchet, The Mode of Deification, op. cit., p. 347 .

I4 J.-C. Larchet, The Mode of Deification, op. cit., p. 347. See further P. Sherwood, The Earlier "Ambigua" of Saint Maximus the Confessor, op. cit., pp. I24-54; J.-C. Larchet, La divinisation de l'homme selon saint Maxime le Confesseur, op. cit., pp. 527-58r.

I5 Amb. Iо (PG 9I, II37BC). 
This may seem to suggest that there is something akin to a transformation of the human nature itself. However, it is more accurate to say, if we wish to understand Maximus' doctrine, that divinisation is a transformation that affects the human creature, which is changed in its tropos or mode of being. It is clear that the deified human beings remain essentially human; they certainly do not become God in essence, and their human nature is not confused with the divine nature itself, just like the humanity of Christ was united with his divinity without being confused with it. ${ }^{16}$

\section{The Problem of Sin and Our Common Humanity}

I wrote earlier that the foundation of theosis is the Incarnation, in which Christ's divine nature envelops his human nature, a human nature like ours in everything except sin. Now, this calls for a further clarification, which concerns the other big issue within the doctrine of theosis, namely the relationship between human nature and sin. From the point of view of our experience, our created nature and our sinful state cannot be fully separated, but conceptually they can and must be distinguished. In Maximus' theology, this second issue is treated especially in the context of the Christological debates surrounding Christ's human will and the heresy of monothelitism, according to which there was in Christ only a single, divine will.

The historical motives of the monothelitist position were complicated and at least in part intertwined with the realpolitik of the Byzantine empire, but the resulting theological questions are permanently relevant. ${ }^{17}$ How could there by a human will in Christ if, in the human will (as we know it), there is a principle of opposition to the divine will? On the other hand, if there was no human will in Christ, in what sense was his humanity the same as ours? How could he have healed what

I6 See J.-C. Larchet, La divinisation de l'homme selon saint Maxime le Confesseur, op. cit., pp. 589-59I.

I7 On the background and issues of the controversy, see for example F.-M. Léthel, Théologie de l'agonie du Christ: La liberté humaine du Fils de Dieu et son importance sotériologique mises en lumière par Saint Maxime Confesseur, Paris 1979, pp. 29-54; A. Louth, Maximus the Confessor, London 1996, pp. 7-16; A. Nichols, Byzantine Gospel: Maximus the Confessor in Modern Scholarship, Edinburgh 1993, pp. I-I5. 
he did not assume? ${ }^{28}$ We may also address the problem differently, and perhaps with greater attention to Protestant concerns: assuming that we take the effects of sin seriously, how can the human being be deified and still remain truly human?

Maximus' conceptual solution to the problem falls back principally, again, on the logos/tropos dyad, although this time with a different application. ${ }^{\text {I9 }}$ The logos of the nature signifies the original purpose and divinely intended dynamism of a created being; the tropos of the hypostasis is the personal mode or way of being, which in the case of the fallen humanity tends to be in tension with, and opposition to, the logos of human nature. There is a fundamental difference between the humanity of Christ and our sinful humanity, but that difference is not situated in our nature.

Christ's humanity is full and perfect humanity, and it includes a fully human will, yet one at the same time entirely consonant with the divine will. The will is an essential faculty of a rational nature, such as the human nature, and without it, Christ would not be human at all. Maximus differentiates between our will and Christ's human will with the help of a distinction between what he calls the natural will (thélêma physikón) and the gnomic or deliberative will (thélêma gnômikón). ${ }^{20}$ They are not separable, but they are distinct, somewhat as the general disposition to will and the act of willing. ${ }^{21}$

I8 This issue is central to Maximus' Opuscula $[=O p$. $] 3$ and I5. An English translation of the former may be consulted in A. Louth, Maximus the Confessor, op. cit., pp. I92-I98.

I9 For a detailed explanation, see F.-M. Léthel, Théologie de l'agonie du Christ, op. cit., pp. 65-99; A. Louth, Maximus the Confessor, op. cit., pp. 48-62; I.A. MacFarland, The Theology of the Will, in: The Oxford Handbook of Maximus the Confessor, op. cit.,

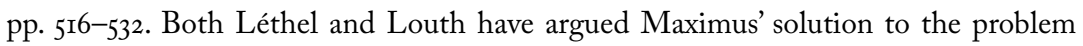
of Christ's human will is quite novel, even though he never presented himself as an innovator: F.-M. Léthel, La prière de Jesus à Gethsémani dans la controverse monothélite, in: Maximus Confessor: Actes du Symposium sur Maxime le Confesseur, eds. F. Heinzer, Ch.von Schönborn, Fribourg 1982, pp. 207-214; A. Louth, Maximus the Confessor, op. cit., p. 62.

20 I have followed Louth in translating the latter (gnômikon) as deliberative will. For an explanation, see A. Louth, Maximus the Confessor, op. cit., p. 217 n. 24.

2I See for example $O p \cdot 3,{ }_{45} \mathrm{D}-48 \mathrm{~A}$, in which Maximus explains that "to be disposed by nature to will and to will are not the same thing, as it is not the same thing 
Maximus' notion of the natural will corresponds to the natural faculty or power of willing, proper to a rational being, whereas the gnomic or deliberative will is the free determination of the natural will by the willing subject, that is, the person or hypostasis. We might say that Christ's human will is supremely natural because it is in full accord with the logos of human nature, which is ultimately nothing other than to be an image and likeness of God.

\section{The Ways of Freedom and Our Healing}

The notion of the gnomic or deliberative will in Maximus' thinking is derived from the Greek term gnomê, which may be translated as deliberation, opinion, intention etc. It is proper to human nature as we ordinarily know it that the determination of the natural will must be subject to an act of deliberation. One might perhaps express this by saying that the freedom of the human person (at least in our present state) manifests itself in this act of deliberation. Maximus would point out, however, the act of deliberation is an imperfect form of freedom, because it does not necessarily lead to the choice of the good. In other words, the gnomic aspect of our mode of making choices does not refer to the fact that we choose freely (which is what we tend to associate with deliberation), but to the fact that (as Louth puts it) "deliberation is what we fall back on when our vision is clouded or confused: it is a measure of our lack of freedom, not the signal exercise of freedom." ${ }_{22}$

In consequence, the contrast between us and Christ is not between human will and (merely) divine will. Rather, in Christ there is no deliberative will as in us, because there is a full harmony between his divine bypostasis and his human nature. It is not that Christ does not make

to be disposed by nature to speak and to speak. For the capacity for speaking is always naturally there, but one does not always speak, since what belongs to the essence is contained in the principle of the nature, while what belongs to the wish is shaped by the intention [gnômê] of the one who speaks. So being able to speak always belongs to the nature, but how you speak belongs to the hypostasis. So it is with being disposed by nature to will and willing." (English translation according A. Louth, Maximus the Confessor, op. cit., p. 193).

22 A. Louth, Maximus the Confessor, op. cit., p. 62. 
choices, but that he does not make them like we do, because he sees with clarity that which he ought to choose, and he chooses it without hesitation. ${ }^{23}$

In our sinful humanity, there is an imperfect mode of being (tropos) that is in conflict with and even in opposition to the logos of human nature, and this conflict and opposition resides principally in the will. The logos of human nature remains stable and unchanged in both sin and redemption. The gnomic or deliberative will is one of the consequences of sin: it means that the intellect has lost its full natural capacity and is mixed up with the irrational; humanity is in a state of fragmentation and confusion, as well as mortality.

A useful analogy may be found in the way a disease manifests itself. An ill human being is not a "non-human being," and the same holds for other animals. But sick animals have a less perfect participation in the nature of that animal, their operations are limited and their participation in life is weaker. Symptoms are not the cause of the illness; the cause is interior. Sin is a state of spiritual illness which resides especially in the spiritual faculties of the intellect and the will. These have an effect on the whole human being: passions, which were originally ("naturally") good, now may operate against human nature, because they are directed towards self-love. ${ }^{24}$

Theosis or deification is therefore understood by Maximus as a process in which divine grace heals the distorted mode of being. This healing includes a restoration of the will, so that a deified human being becomes able to think and want and even feel in a way that is at once truly human and divine. The process is essentially a divine work, but it does not take place without the free consent of the human subject. The consent of the human creature to the process of healing at least ordinarily includes such elements as prayer, sacramental and liturgical life, ascesis and mortification, and generally the practice of virtue. The supreme goal of all this is charity, the divine virtue which most fully likens us to God.

On the one hand, it is clear that theosis is not a destruction of human nature, but quite the contrary. A life of virtue is a way of life "according to nature" (kata physin), that is to say, according to the logos

23 See for example Op. 3, 48B-D.

24 On Maximus' doctrine of the passions, see D. Bathrellos, Passions, Ascesis, and the Virtues, in: The Oxford Handbook of Maximus the Confessor, op. cit., pp. 287-306. 
of our nature, and fulfils the divine plan inscribed in it. On the other hand, this means that the goal of virtue not mere human perfection in an earthly sense, but deification (theosis). The four cardinal virtues are ultimately transformed into love as the most generic genus of all the virtues. This is to "become living images of Christ, or rather become one with Him through grace (rather than being a mere simulacrum), or even, perhaps, to become the Lord himself, if such an idea is not too onerous for some to bear." ${ }^{25}$

\section{Understanding Luther through MaXimus?}

I said in the introduction that I wished to present Maximus as someone who may help us go forward in our mutual understanding in ecumenical dialogue, especially in relation to the prospect of a common, or least very close, doctrine of deification or theosis. This doctrine is sometimes presented as an exclusive patrimony of the Eastern Fathers, but many would argue that its essential content (and partly the vocabulary) is very much present in the Western tradition also. ${ }^{26}$ Moreover, as we saw earlier, there are arguments in favour of this doctrine even in Luther.

From a Catholic point of view, this so-called Finnish interpretation of Luther has remained relatively unknown. ${ }^{27}$ When it is known, there are still major concerns pertaining to the meaning and significance of this doctrine within the broader theology of Luther. Pedro Urbano, for example, has argued that in spite of the potential of this interpretation, there are major differences in the way in which the doctrine should be understood. ${ }^{28} \mathrm{He}$ acknowledges that in Luther we may speak

$25 A m b .2 \mathrm{I}$ (PG 9I, I253D).

26 See for example P. Urbano, Theosis: La doctrina de la divinización en las tradiciones cristianas. Fundamentos para una teología ecuménica de la gracia, Pamplona $200 \mathrm{I}$

27 Not entirely, of course. For an interested but critical evaluation, see for example P. Urbano, Christus in fide adest. Cristo presente en el creyente o la teologia de la deification in Lutero, "Scripta Theologica" 32 (2000), pp. 757-799; P. Urbano, Theosis, op. cit., pp. $238-26 \mathrm{I}$.

28 P. Urbano, Christus in fide adest. Cristo presente en el creyente o la teologia de la deification in Lutero, "Scripta Theologica" 32 (2000), pp.796-799; P. Urbano, Theosis, op. cit., pp. $259^{-261}$. 
of an ontological transformation, but Luther's view of the fallen human nature seems to preclude any change of nature or an elevation of the natural capacities of man.

It is beyond my scope to propose an interpretation of Luther here, but let me only point out some of the ways in which Maximus' categories and terminology may help to clarify the commonalities and differences between Luther and others. Seen through the ontological categories of Maximus the Confessor, Luther's view of the fallen human nature seems to correspond not to nature at all but the sinful mode of being. Although Maximus is more optimistic than Luther concerning the prospects of a transformation and insists more on the permanency of the created human nature that remains good, they may coincide in locating the transformation operated by God not in nature but in the existential state or way of being.

It could be argued that Maximus' vision is nothing but a conceptual clarification of the biblical anthropology in which the sinful tropos of humanity essentially corresponds to the Pauline flesh, whereas the logos of human nature is the imago Dei, or something like that. If this is true, it is not surprising if we find strong commonalities between Maximus and Luther, at least as far as the problem of sin is concerned. There may be a way out of the dead end of Lutheran theosis doctrine (to which Urbano alludes to) if we interpret Luther as meaning that man is a sinner not metaphysically but existentially: not in terms of the logos of his nature but his personal tropos. This interpretation may also help Lutherans to embrace elements of Catholic and Orthodox anthropology and spiritual practice, when it is understood that they are not intended as means of self-transformation by merely human powers, but as ways of opening up to the grace that acts upon us and gradually works on us on the inside.

\section{Conclusion}

Maximus the Confessor's doctrine of theosis is situated at the centre of his theological vision, which ultimately encompasses the deification of the universe in the divine Logos. The ontological foundation of deification is the Incarnation of the Logos, which implies the perichoresis or mutual compenetration of human and divine natures. Human beings have the possibility of welcoming the divine activity (grace) into 
their own nature and being moved and transformed by it. Maximus conceptually clarifies how this is possible without destroying or annihilating the created nature. In the fullness of deification, all men can say with Paul, "It is no longer I who live, but Christ who lives in me" (Gal. 2:20).

Maximus, I would argue, probably represents one of the clearest and the conceptually most accurate accounts of theosis, and he may help to clarify the mind and meaning of other Eastern and Western thinkers alike. He may even help to clarify the mind of Luther, even if they obviously do not coincide in everything. In favour of this proposal, it should be remembered that Luther's strength was not in systematic theology and much less in philosophical ontology, but rather in the theological description of certain Christian experiences, which by their nature are highly complex.

\section{BIBLIOGRAPHY}

Bathrellos D., Passions, Ascesis, and the Virtues, in: The Oxford Handbook of Maximus the Confessor, eds. P. Allen, B. Neil, Oxford 2015, pp. 287-306.

Garrigues J.M., Maxime le Confesseur: La Charité, avenir divin de l'homme, Paris 1976.

Larchet J.-C., La divinisation de l'homme selon saint Maxime le Confesseur, Paris I996.

Larchet J.-C., The Mode of Deification, in: The Oxford Handbook of Maximus the Confessor, eds. P. Allen, B. Neil, Oxford 2015, pp. 34I-359.

Léthel F.-M., La prière de Jesus à Gethsémani dans la controverse monothélite, in: Maximus Confessor: Actes du Symposium sur Maxime le Confesseur, eds. F. Heinzer, Ch. von Schönborn, Fribourg 1982, pp. 207-214.

Léthel F.-M., Théologie de l'agonie du Christ: La liberté bumaine du Fils de Dieu et son importance so-tériologique mises en lumière par Saint Maxime Confesseur, Paris 1979.

Louth A., Maximus the Confessor, London 1996.

MacFarland I.A., The Theology of the Will, in: The Oxford Handbook of Maximus the Confessor, eds. P. Allen, B. Neil, Oxford 2015, pp. 516-532.

Mannermaa T., Christ Present in Faith: Luther's View of Justification, Minneapolis 2005 .

Maximus Confessor - Ambigua ad Thomam una cum Epistula secunda ad eundem, ed. B. Janssens, Turnhout 2002 (Corpus Christianorum Series Greaeca 48). 
Maximus the Confessor, On Difficulties in the Church Fathers: The Ambigua, ed. and trans. N. Constas, 2 vols., Cambridge, MA 20I4 (Dumbarton Oaks Medieval Library 28-29).

Nichols A., Byzantine Gospel: Maximus the Confessor in Modern Scholarship, Edinburgh 1993 .

The Oxford Handbook of Maximus the Confessor, eds. P. Allen, B. Neil, Oxford 2015.

Perl E., Methexis: Creation, Incarnation, Deification in Saint Maximus Confessor, $\mathrm{PhD}$ dissertation, Yale University I99I.

Sherwood P., The Earlier "Ambigua" of Saint Maximus the Confessor and His Refutation of Origenism, Rome I955.

Thunberg L., Man and the Cosmos: The Vision of St. Maximus the Confessor, Crestwood i985.

Thunberg L., Microcosm and Mediator: The Theological Anthropology of Maximus the Confessor, and ed., Chicago I995.

Union with Christ: The New Finnish Interpretation of Luther, eds. C.E. Braaten, R.W. Jenson, Grand Rapids 1998.

Urbano P., Christus in fide adest. Cristo presente en el creyente o la teologia de la deification en Lutero, "Scripta Theologica" 32 (2000), pp. 757-799.

Urbano P., Theosis: La doctrina de la divinización en las tradiciones cristianas. Fundamentos para una teología ecuménica de la gracia, Pamplona $200 \mathrm{I}$. 